\title{
Early Changes in Nitrate Uptake and Assimilation Under Drought in Relation to Transpiration
}

\author{
Vit Gloser ${ }^{1 *}$, Michaela Dvorackova ${ }^{1}$, Daniel Hernandez Mota ${ }^{1}$, Bojana Petrovic ${ }^{1}$, \\ Patricia Gonzalez ${ }^{2}$ and Christoph Martin Geilfus ${ }^{2}$
}

'Department of Experimental Biology, Faculty of Science, Masaryk University, Brno, Czechia, ${ }^{2}$ Division of Controlled Environment Horticulture, Faculty of Life Sciences, Albrecht Daniel Thaer-Institute of Agricultural and Horticultural Sciences, Humboldt-University of Berlin, Berlin, Germany

OPEN ACCESS

Edited by:

Carla S. Santos,

Catholic University of Portugal,

Portugal

Reviewed by:

Yordan Muhovski,

Walloon Agricultural Research

Centre, Belgium

Jaime Puertolas,

Lancaster University, United Kingdom

*Correspondence:

Vit Gloser

vitgloser@sci.muni.cz

Specialty section:

This article was submitted to

Plant Nutrition,

a section of the journal

Frontiers in Plant Science

Received: 02 September 2020 Accepted: 04 December 2020 Published: 23 December 2020

Citation: Gloser V, Dvorackova M, Mota DH, Petrovic B, Gonzalez P and Geilfus CM (2020) Early Changes in Nitrate Uptake and Assimilation Under Drought in Relation to Transpiration.

Front. Plant Sci. 11:602065. doi: 10.3389/fp/s.2020.602065
Soil drying combined with nitrogen $(\mathrm{N})$ deficiency poses a grave threat to agricultural crop production. The rate at which nitrate $\left(\mathrm{NO}_{3}{ }^{-}\right)$is taken up depends partly on the uptake and transpiration of water. Rapid changes in nitrate assimilation, in contrast to other $\mathrm{N}$ forms, may serve as a component of the plant stress response to drought because nitrate assimilation may lead to changes in xylem $\mathrm{pH}$. The modulation of xylem sap $\mathrm{pH}$ may be relevant for stomata regulation via the delivery of abscisic acid (ABA) to guard cells. In several factorial experiments, we investigated the interactions between nitrate and water availability on nitrate fate in the plant, as well as their possible implications for the early drought-stress response. We monitored the short-term response (2-6 days) of nitrate in biomass, transport to shoot and reduction in Pisum sativum, Hordeum vulgare, Vicia faba, and Nicotiana tabacum and correlated this with sap $\mathrm{pH}$ and transpiration rates (TRs). Cultivation on inorganic substrate ensured control over nutrient and water supply and prevented nodulation in legume species. $\mathrm{NO}_{3}{ }^{-}$content in biomass decreased in most of the species under drought indicating significant decline in $\mathrm{NO}_{3}{ }^{-}$uptake. Hordeum vulgare had the highest $\mathrm{NO}_{3}{ }^{-}$concentrations in all organs even under drought and low $\mathrm{NO}_{3}{ }^{-}$ treatment. This species can likely respond much better to the combined adverse effects of low $\mathrm{NO}_{3}{ }^{-}$and water scarcity. Nitrate reductase activity (NRA) was reduced in both roots and leaves of water deficient (WD) plants in all species except $H$. vulgare, presumably due to its high $\mathrm{NO}_{3}{ }^{-}$contents. Further, transient reduction in $\mathrm{NO}_{3}{ }^{-}$availability had no effect on sap $\mathrm{pH}$. Therefore, it seems unlikely that NRA shifts from shoot root leading to the supposed alkalization of sap. We also did not observe any interactive effects of $\mathrm{NO}_{3}{ }^{-}$and water deficiency on transpiration. Hence, as long as leaf $\mathrm{NO}_{3}{ }^{-}$content remains stable, $\mathrm{NO}_{3}{ }^{-}$availability in soil is not linked to short-term modulation of transpiration.

Keywords: nitrate transport, nitrogen deficiency, nitrate reductase, $\mathrm{pH}, \mathrm{xylem}$, apoplast

\section{INTRODUCTION}

Nitrate $\left(\mathrm{NO}_{3}{ }^{-}\right)$is a very important nitrogen $(\mathrm{N})$ source for almost all plants, particularly crop plants. Fluctuations in $\mathrm{NO}_{3}^{-}$availability considerably alter both rates of $\mathrm{NO}_{3}^{-}$transport and assimilation (i.e., reduction) within the plant (Peuke et al., 1996; Lips, 1997). When external $\mathrm{NO}_{3}{ }^{-}$availability decreases, its transport to the plant and to the shoot is typically reduced (Hachiya and Sakakibara, 2017). Low $\mathrm{NO}_{3}^{-}$availability can also lower the transpiration rate 
(TR; Wilkinson et al., 2007) and consequently affect water use by crops. Araus et al. (2020) showed that changes in $\mathrm{NO}_{3}{ }^{-}$ availability may lead to changes in the expression of droughtresponse genes; this response also involves the drought stress hormone abscisic acid (ABA). An interesting detail is that nitrogen supply to roots enhances stomatal opening, provided that plants are well watered (Wilkinson et al., 2007; Matimati et al., 2014). Conversely, nitrogen deficiency can cause rapid reduction of gas exchange (Chapin et al., 1988). This response can occur without any change in leaf water potential (WP); it is mediated by increased ABA production and a consequent decrease in gas exchange similar to the response to water deficiency (Chapin, 1991). The $\mathrm{N}$ status of the plant also influences gas exchange because $\mathrm{N}$ is involved in many processes related to photosynthesis (Lu and Zhang, 2000). The variation in the rate of carbon fixation and, consequently in leaf intercellular $\mathrm{CO}_{2}$ concentration, strongly affects stomatal aperture (Roelfsema et al., 2002, 2006). Additionally, the rate of ATP generation in the primary processes of photosynthesis is also one of the regulators of stomatal conductance (Tezara et al., 1999; Tominaga et al., 2001).

Thus, there seems to be a link between nitrogen $\left(\mathrm{NO}_{3}{ }^{-}\right)$ availability and the response to drought. Moreover, decreasing water availability in soil can negatively affect $\mathrm{NO}_{3}{ }^{-}$uptake and assimilation (Lawlor and Cornic, 2002; Azedo-Silva et al., 2004). Nevertheless, it is not completely clear whether these early changes in $\mathrm{NO}_{3}^{-}$metabolism can also serve as a component of the plant stress response system. For an overall summary of the interdependence of water and nitrogen use, the reader is referred to the recent review by Plett et al. (2020).

Experimental evidence also indicates that changes in $\mathrm{NO}_{3}{ }^{-}$ availability even within the non-deficient range may have a rapid regulatory effect on stomatal opening (Wilkinson et al., 2007). The underlying mechanism may involve changes in xylem sap $\mathrm{pH}$, which is relevant for the compartmental distribution of ABA between mesophyll cells and the guard cell apoplast (Wilkinson et al., 1998; Davies et al., 2002; Geilfus et al., 2015). This ABA is likely being produced in the shoot (Dodd et al., 2009; McAdam et al., 2016; Li et al., 2018). For example, apoplastic alkalization during drought or other environmental stresses promotes $\mathrm{ABA}$ accumulation in the guard cell apoplast and triggers stomatal closure (Wilkinson and Davies, 2002; Geilfus et al., 2017). Notably, increasing $\mathrm{NO}_{3}^{-}$levels was also reported to increase leaf apoplast pH (Jia and Davies, 2007). This could be due to altered $\mathrm{NO}_{3}{ }^{-}$assimilation, via altered $\mathrm{NO}_{3}{ }^{-}$reductase activity (NRA; Wilkinson, 2004).

Nitrate assimilation is a relevant factor for apoplastic $\mathrm{pH}$ because of the number of electrons required to reduce $\mathrm{NO}_{3}{ }^{-}$ to $\mathrm{NH}_{4}{ }^{+}$. As a result, strongly basic hydroxides are formed, which are buffered by newly synthesized organic acids (i.e., malic acid) as otherwise the alkalizing hydroxides can drastically alter cytosolic pH (Dijkshoorn, 1962). Transporting organic acid anions (e.g., malate ${ }^{2-}$ ), into the apoplast is considered as the cause for the depletion of free apoplast protons. In the slightly acidified apoplast, free protons associate with the malate anion, thereby increasing the $\mathrm{pH}$. Nonetheless, the relevance of drought for this apoplastic $\mathrm{pH}$-modulating effect is still unclear.
Drought is known to increase apoplastic $\mathrm{pH}$, as shown for field bean (Karuppanapandian et al., 2017), sunflower (Gollan et al., 1992), asiatic dayflower (Commelina communis; Wilkinson and Davies, 1997), or maize (Goodger et al., 2005). Drought also has a significant effect on NRA in some species (Larsson et al., 1989; Azedo-Silva et al., 2004; Correia et al., 2005). Limited availability of $\mathrm{NO}_{3}^{-}$as substrate for NRA due to the reduced uptake and transport under drought is one possible explanation for the downregulation of NRA (Azedo-Silva et al., 2004). NRA may also decrease due to lower NR activation under drought (Brewitz et al., 1996; Foyer et al., 1998). Moreover, the response of NRA to water availability may differ between species that differ in the primary site of $\mathrm{NO}_{3}{ }^{-}$reduction (root vs. leaves), but to our knowledge no data on this has been published so far.

Given that resource availability in the environment fluctuates greatly over time, rapid plant responses to any fluctuations may significantly impact productivity. The interrelation between water availability and both uptake and reduction of $\mathrm{NO}_{3}{ }^{-}$could be relevant for transpiration by modulating xylem sap $\mathrm{pH}-\mathrm{a}$ factor that is linked to controlling plant transpiration and gas exchange in general. Besides the role of $\mathrm{NO}_{3}{ }^{-}$in plant metabolism, in contrast to other $\mathrm{N}$ forms available in the soil, is its uptake more tightly linked to water movement toward plant roots (Marschner, 1995). Any assessment of the hypothesis on the relevance of $\mathrm{NO}_{3}{ }^{-}$for transpiration must consider species-specific differences in the ability to take up and reduce $\mathrm{NO}_{3}^{-}$under drought. Thus, four species were evaluated that contrast in their nitrogen uptake and assimilation: Pisum sativum, Hordeum vulgare, Vicia faba, and Nicotiana tabacum. Moreover, the differential ability of diverse species to change xylem sap $\mathrm{pH}$ under drought stress is also certainly relevant (Sharp and Davies, 2009; Gloser et al., 2016). In this paper, we describe a series of experiments where we investigated the interactions between $\mathrm{NO}_{3}{ }^{-}$availability and water availability and their implication for the early drought-stress response. The possible effect of the dominant site of $\mathrm{NO}_{3}^{-}$assimilation inside the plant on its drought response is also discussed.

\section{MATERIALS AND METHODS}

\section{Plant Material and Cultivation}

Four species were used in experiments: green pea ( $P$. sativum $\mathrm{cv}$. Premium), spring barley (H. vulgare $c v$. Heris), bean (V. faba cv. Merkur), and tobacco (N. tabacum cv. GAT). Species differ in the distribution of NRA between roots and leaves (Andrews, 1986), as well as in the changes of xylem sap composition under water deficiency (Gloser et al., 2016). Plants were cultivated with the inorganic substrate Profile Porous Ceramic (PPC, PROFILE Products LLC, Buffalo Grove, IL, United States). This was done to ensure full control of nutrient availability. In all experiments, plants were initially grown in a greenhouse with temperature and humidity control. Five days before the drying treatment started, plants were moved to a growth chamber with $16 / 8 \mathrm{~h}$ light/dark photoperiod and the following conditions: mean photosynthetic photon flux density 
$400 \mu \mathrm{mol} \mathrm{m} \mathrm{m}^{-2} \mathrm{~s}^{-1}$, average temperature of $22^{\circ} \mathrm{C}$ (light) and $20^{\circ} \mathrm{C}$ (dark), and relative humidity $60 \%$ (constant). The position of plants for different treatments in the chamber was randomized. Due to the supply of $\mathrm{NO}_{3}^{-}$, there were no nodules on roots of the legumes $V$. faba and P. sativum.

Five days after moving the plants to the growth chamber (day 0), two different experiments were started. In experiment 1, 40 plants of each of the four species were separated into two treatments. Irrigation was stopped in the water deficient (WD) treatment for 10 days, whereas well-watered (WW) plants were irrigated daily to full water holding capacity of the substrate with nutrient solution containing: $1.21 \mathrm{mM} \mathrm{Ca}\left(\mathrm{NO}_{3}\right)_{2}, 1.6 \mathrm{mM}$ $\mathrm{KNO}_{3}, 380 \mu \mathrm{M} \mathrm{KH} \mathrm{PO}_{4}, 540 \mu \mathrm{M} \mathrm{MgSO}_{4}, 4 \mu \mathrm{M} \mathrm{MnSO}_{4}, 1.7 \mu \mathrm{M}$ $\mathrm{ZnSO}_{4}, 0.3 \mu \mathrm{M} \mathrm{CuSO}_{4}, 40 \mu \mathrm{M}, \mathrm{H}_{3} \mathrm{BO}_{3}, 0.5 \mu \mathrm{M} \mathrm{Na}_{2} \mathrm{MoO}_{4}$, and $81 \mu \mathrm{M}$ FeNa-EDTA (4 mM NO${ }_{3}^{-} \mathrm{N}$ in total). Experiment 2 was a two-factorial experiment with water and nitrogen availability as factors. About 60 plants of $V$. faba and P. sativum were divided into the same two treatments as experiment 1 at day 0, i.e., in $30 \mathrm{WW}$ and $30 \mathrm{WD}$ plants. The 30 plants of each water treatment were then separated into two group's á 15 plants. At day 0 , in order to wash out the remaining nitrogen, containers of the plants that were supposed to experience lack of nitrogen were flushed with a large amount of nitrogen solution containing: $60.3 \mu \mathrm{M} \mathrm{Ca}\left(\mathrm{NO}_{3}\right)_{2}, 79.5 \mu \mathrm{M}$

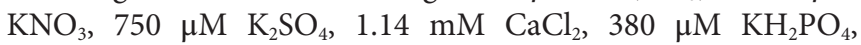
$540 \mu \mathrm{M}, \mathrm{MgSO}_{4}, 4 \mu \mathrm{M} \mathrm{MnSO}_{4}, 1.7 \mu \mathrm{M} \mathrm{ZnSO}_{4}, 0.3 \mu \mathrm{M} \mathrm{CuSO}_{4}$, $40 \mu \mathrm{M}, \mathrm{H}_{3} \mathrm{BO}_{3}, 0.5 \mu \mathrm{M} \mathrm{Na} \mathrm{MoO}_{4}$, and $81 \mu \mathrm{M}$ FeNa-EDTA [0.2 $\mathrm{mM} \mathrm{NO}_{3}^{-} \mathrm{N}$ in total; plants from this experimental group are named "low nitrogen (LN) plants"]. The missing $\mathrm{NO}_{3}{ }^{-}$in LN solution was replaced with sulphate to retain both ionic and osmotic parity between treatments. Plants in "full nitrogen (FN) treatment" were watered with the initial solution described above. Model calculations based on solution volume retained (or additionally supplied) in each container, and composition of the solution showed large differences in total nitrate potentially available to plants during the experimental period when drying was applied, particularly between $\mathrm{HN}$ and $\mathrm{LN}$ treatments: WWHN: $3.1 \mathrm{mmol}$, WDHN $1.7 \mathrm{mmol}$, WWLN: $0.15 \mathrm{mmol}$, and WDLN: $0.08 \mathrm{mmol}$. Plant response was monitored regularly for up to 10 days after the start of treatments, making three harvests every 2-3 days.

\section{Measurements of Soil and Plant Water Relations}

Substrate water content (SWC) was monitored using a ThetaProbe connected to a $\mathrm{HH} 2$ meter (Delta- $\mathrm{T}$ Devices, Cambridge, United Kingdom). SWC was also measured in each pot immediately prior to harvesting. The relationship between substrate WP and SWC is shown in Supplementary Figure S1 (Supplementary Material). Whole plant TR was determined gravimetrically prior to xylem sap collection. TR was measured at least for $1 \mathrm{~h}$ under normal cultivation conditions, and plant containers were covered with a plastic bag to prevent evaporation from the substrate. Plant leaf area was determined at the end of sampling using a scanner and the image analysis software ImageJ (NIMH, Bethesda, $\mathrm{MD}$, United States). WP of the plant was measured either on young fully developed leaves or on the top part of the shoot (depending on the species), using the pressure chamber method before xylem sap sampling (see below).

\section{Xylem Sap Collection and Analysis}

The collection of xylem sap and the measurement of leaf/stem WP (Boyer, 1967) and xylem sap pH were conducted between 2 and $7 \mathrm{~h}$ from photoperiod start. Xylem sap was collected either from leaf (N. tabacum) or stems (P. sativum, H. vulgare, and $V . f a b a$ ) using a pressure chamber (PWSC 3005, Soilmoisture Equipment Corp., Santa Barbara, CA, United States). Sap was sampled from the second or third fully developed leaf of $N$. tabacum. After cutting, the cut surface of the petiole/stem was rinsed with distilled water to remove contaminants from the cut cells and the petiole/stem was sealed in the pressure chamber. The first drop of xylem sap was discarded and the pressure was noted as the WP. Pressure was gradually increased up to approx. Around $0.2 \mathrm{MPa}$ above the balancing pressure and 10-40 $\mu \mathrm{l}$ of xylem sap was collected from each leaf (or shoot) over approximately $10 \mathrm{~min}$. The $\mathrm{pH}$ of xylem sap was taken by a $\mathrm{pH}$ microelectrode (Microelectrodes Inc., Bedford, MA, United States) connected to an MP220 pH meter (Mettler Toledo, Switzerland). Samples were stored at $-20^{\circ} \mathrm{C}$ immediately after $\mathrm{pH}$ measurement, until further analysis.

\section{Determination of Nitrate in Biomass and Sap, Calculation of Delivery Rates}

Nitrate was extracted from $50 \mathrm{mg}$ of fresh biomass in $1 \mathrm{ml}$ of hot $\left(95^{\circ} \mathrm{C}\right)$ DI water for $30 \mathrm{~min}$. $\mathrm{NO}_{3}{ }^{-}$concentration in the extract as well as in the xylem sap samples was consequently assayed by a spectrophotometric method (Cataldo et al., 1975). The delivery rate of $\mathrm{NO}_{3}^{-}$was calculated as sap $\mathrm{NO}_{3}^{-}$ concentration multiplied by water flux to leaves $\left(\mathrm{g} \mathrm{h}^{-1}\right)$ derived from the gravimetric TR measurement of the respective plant shortly before sap sampling.

\section{Nitrate Reductase Activity}

Nitrate reductase activity was estimated in leaves and roots with an in vivo assay (Black et al., 2002). Four subsamples of leaf disks $(\sim 100 \mathrm{mg})$ or finely chopped roots $(\sim 200 \mathrm{mg})$ were combined with $5 \mathrm{ml}$ of assay buffer $\left(200 \mathrm{~mol} \mathrm{~m}^{-3} \mathrm{KNO}_{3}\right.$ and $5 \%$ propanol in $100 \mathrm{~mol} \mathrm{~m}^{-3}$ potassium phosphate buffer, $\mathrm{pH}$ $7.5)$ in $20 \mathrm{ml}$ glass vials. The vials were closed and placed in the dark at $25^{\circ} \mathrm{C}$ on a shaker. Two replicate vials for each sample were removed from the shaker after 10 and $90 \mathrm{~min}$ and placed in boiling water for $15 \mathrm{~min}$. The vials were cooled to room temperature and aliquots of assay buffer were collected and stored at $-20^{\circ} \mathrm{C}$. To determine nitrite concentration, $500 \mathrm{ml}$ of $1 \%$ sulphanilamide in $3 \mathrm{M} \mathrm{HCl}$ and $500 \mathrm{ml}$ of $0.02 \%$ $\mathrm{N}$-naphthyl-ethylene-diamine hydrochloride in water were added to the thawed samples and kept in the dark at room temperature for $20 \mathrm{~min}$, and the absorbance measured at $540 \mathrm{~nm}$. Enzyme activity was calculated by comparing the amount of nitrite produced after 90-min incubation with that detected after 10 min (Black et al., 2002). We took the mean of two replicates and expressed NRA as $\mu \mathrm{mol}$ nitrite produced $g$ (Fresh Mass) $^{-1}$ (fine roots or leaves) $\mathrm{h}^{-1}$. 


\section{Statistical Evaluation}

The effect of drought was tested on WD and WW control plants. However, the different species and the various treatments differed in drying rates. To enable meaningful comparison across treatments and species, we used information about SWC and TR of each plant shortly before harvest. Plants were grouped such that both SWC and TR of WD plants were significantly lower than those of WW plants. WD treatment typically included plants with SWC $0.6 \mathrm{~g} \mathrm{~g}^{-1}$ and lower. Statistical analyses were performed using STATISTICA 12 (TIBCO Software Inc., Palo Alto, CA, United States). In the first group of results - comparison of the response to drought under full $\mathrm{NO}_{3}{ }^{-}$supply - significant differences between means WW and WD treatments were tested by a $t$-test separately for species and parameter. In experiments with a two-factorial design, the combined effects of drought and $\mathrm{N}$-deficiency were tested by a two-way ANOVA for each species separately. Normality of data and homogeneity of variances were tested prior to analysis and non-homogeneous datasets were log transformed. Spearman's correlation analysis was used to evaluate the significance of correlations between the measured parameters. Correlation analyses included data of all harvested plants of each species.

\section{RESULTS}

\section{Effect of Water Availability on Plant Water Relations}

A fall in water availability to approximately $50-60 \%$ of the maximum substrate water holding capacity $\left(\mathrm{SWC}=1.1 \mathrm{~g} \mathrm{~g}^{-1}\right)$ led to a significant decrease in the TR and the leaf WP in all examined species (Table 1). The decrease was particularly pronounced (approximately 50\%) in N. tabacum and P. sativum. Nicotiana tabacum showed a significant decrease in WP with the value being three times lower relative to $\mathrm{WW}$-conditions.

\section{Effect of Water Availability on $\mathrm{NO}_{3}{ }^{-}$ Content}

Water deficient treatment significantly reduced $\mathrm{NO}_{3}{ }^{-}$content in roots and leaves in three of the examined species and they also differed considerably in their response (Table 2). In V. faba,

TABLE 1 | Mean soil water content (SWC), whole plant TR and the leaf WP of plants with full water supply (well-watered; WW) and plant exposed to gradual drying of substrate for several days (water-deficient; WD).

\begin{tabular}{lllcc}
\hline \multicolumn{1}{c}{ Species } & Treatment & SWC $\left(\mathbf{g ~ g ~}^{-1}\right)$ & TR $\left(\mathbf{g ~ m}^{-2} \mathbf{h}^{-1}\right)$ & WP (MPa) \\
\hline Vicia & WW & $0.86 \pm 0.2 \mathrm{a}$ & $159.15 \pm 8.4 \mathrm{a}$ & $-0.24 \pm 0.04 \mathrm{a}$ \\
faba & WD & $0.49 \pm 0.2 \mathrm{~b}$ & $121.80 \pm 10.51 \mathrm{~b}$ & $-0.41 \pm 0.05 \mathrm{~b}$ \\
Nicotiana & WW & $0.84 \pm 0.02 \mathrm{a}$ & $76.5 \pm 7.7 \mathrm{a}$ & $-0.20 \pm 0.04 \mathrm{a}$ \\
tabacum & WD & $0.49 \pm 0.04 \mathrm{~b}$ & $35.8 \pm 8.1 \mathrm{~b}$ & $-0.65 \pm 0.05 \mathrm{~b}$ \\
Pisum & WW & $1.01 \pm 0.01 \mathrm{a}$ & $263.72 \pm 6.3 \mathrm{a}$ & $-0.52 \pm 0.02 \mathrm{a}$ \\
sativum & WD & $0,43 \pm 0.1 \mathrm{~b}$ & $152.50 \pm 18.5 \mathrm{~b}$ & $-0.75 \pm 0.09 \mathrm{~b}$ \\
Hordeum & WW & $0.92 \pm 0.04 \mathrm{a}$ & $146.9 \pm 14.3 \mathrm{a}$ & $-0.54 \pm 0.05 \mathrm{a}$ \\
vulgare & WD & $0.42 \pm 0.1 \mathrm{~b}$ & $96.6 \pm 14.2 \mathrm{~b}$ & $-0.70 \pm 0.05 \mathrm{~b}$ \\
\hline
\end{tabular}

Presented are means and SEs of Vicia faba $(n=13)$, Nicotiana tabacum $(n=17)$, $P$. sativum $(n=31)$, and $H$. vulgare $(n=13)$. Significant differences $(p \leq 0.05)$ between treatments were tested separately for each species and are marked by different letters.

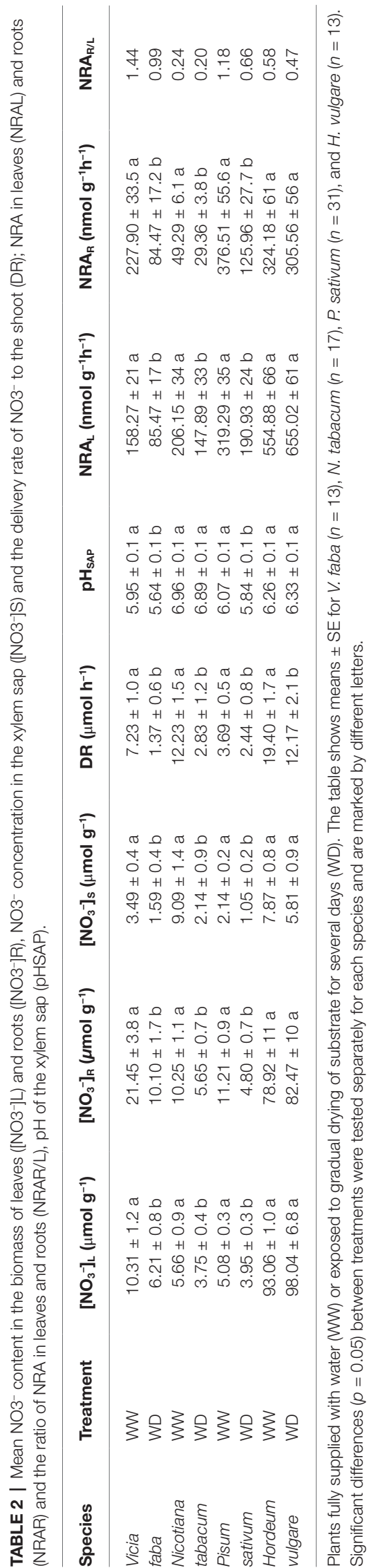

Frontiers in Plant Science | www.frontiersin.org 
N. tabacum and P. sativum, $\mathrm{NO}_{3}^{-}$content was reduced both in leaves and roots in response to WD treatment (Table 2), but leaf $\mathrm{NO}_{3}{ }^{-}$content was not significantly affected in $\mathrm{H}$. vulgare. The concentration of $\mathrm{NO}_{3}{ }^{-}$in xylem sap was also reduced in all species except $H$. vulgare (Table 2 ). The calculated delivery rates of $\mathrm{NO}_{3}{ }^{-}$to leaves were significantly reduced (by 40-80\%) in all species (Table 2). NRA significantly declined in WD treatment (Table 2) but the magnitude of the response was different among the different species. NRA in roots was greatly reduced (by $35-75 \%$ ) in all species. NRA in leaves decreased in $V$. faba, P. sativum, and N. tabacum but not in H. vulgare (Table 2).

\section{Impact of Nitrogen Deficiency Under Drought}

In $P$. sativum and $H$. vulgare, we studied the combined effects of water scarcity and lowered nitrogen availability in more detail. Contrary to expectations, reduction in $\mathrm{NO}_{3}{ }^{-}$availability for several days had no negative effect on TR in either species (Figure 1; Table 3). Reduced $\mathrm{NO}_{3}{ }^{-}$availability caused a significant reduction of $\mathrm{NO}_{3}{ }^{-}$content in roots of both species but leaf content was not reduced in P. sativum (Figure 2; Table 3). The fall in TR under drought was similar under full or reduced

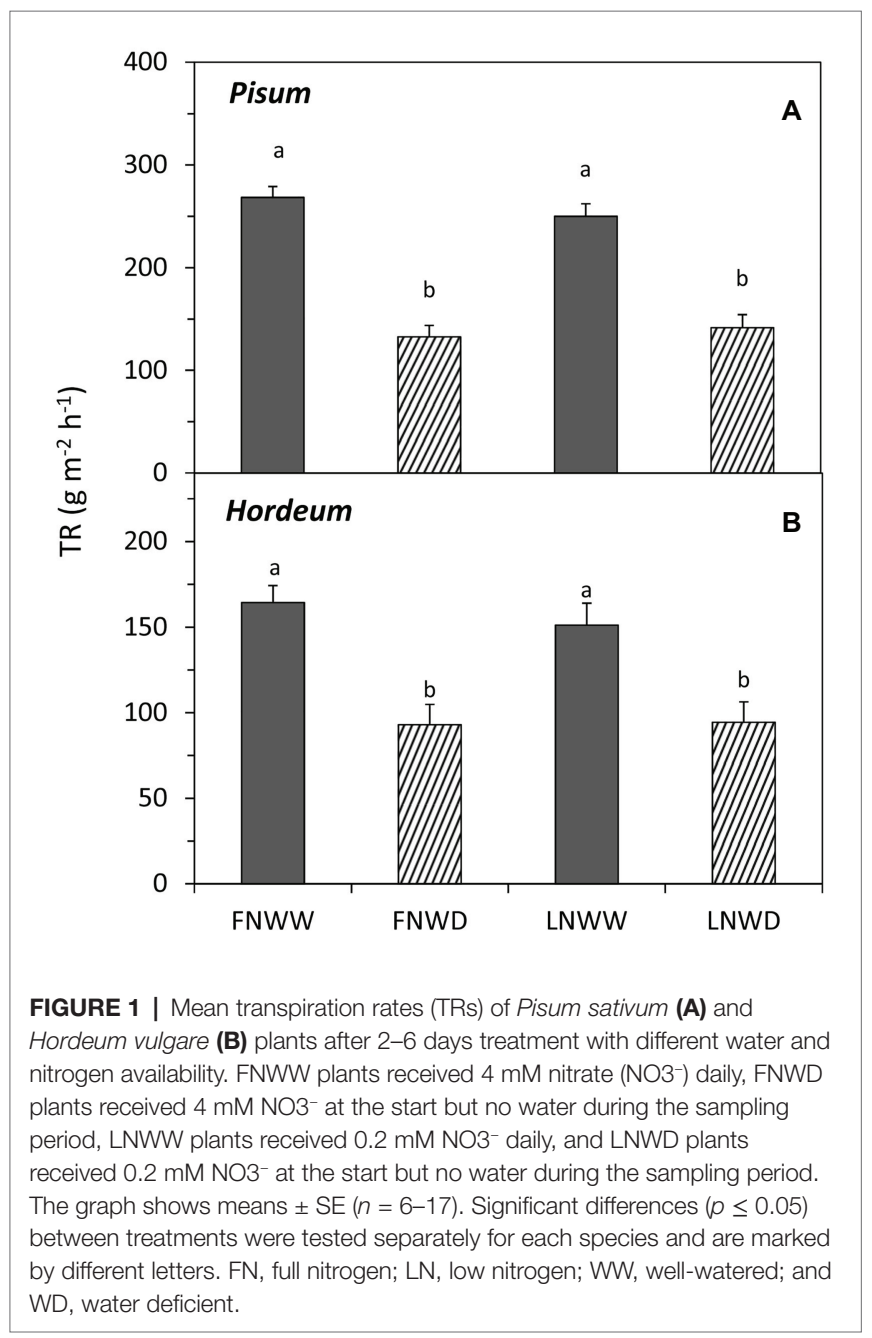

$\mathrm{NO}_{3}^{-}$supply (Figure 1). WP of $P$. sativum decreased under water limitation, but in $H$. vulgare the decrease was not significant (Figure 3; Table 3).

Regression analysis revealed that the WP decrease in $\mathrm{FN}$ treatment occurred under higher SWC (Figure 3B) than in LN

TABLE 3 | Significance of the experimental factors and their interaction was analyzed by two-way ANOVA.

\begin{tabular}{|c|c|c|c|c|c|c|}
\hline \multirow[t]{2}{*}{ Trait } & \multicolumn{3}{|c|}{ Pisum sativum } & \multicolumn{3}{|c|}{ Hordeum vulgare } \\
\hline & Water & Nitrogen & $\mathbf{W} \times \mathbf{N}$ & Water & Nitrogen & $\mathbf{W} \times \mathbf{N}$ \\
\hline TR & 0.000 & 0.683 & 0.251 & 0.000 & 0.536 & 0.618 \\
\hline WP & 0.000 & 0.460 & 0.550 & 0.115 & 0.561 & 0.059 \\
\hline$\left[\mathrm{NO}_{3}^{-}\right]_{\mathrm{L}}$ & 0.197 & 0.960 & 0.082 & 0.718 & 0.000 & 0.472 \\
\hline$\left[\mathrm{NO}_{3}^{-}\right]_{\mathrm{R}}$ & 0.000 & 0.000 & 0.854 & 0.698 & 0.000 & 0.420 \\
\hline $\mathrm{NRA}_{L}$ & 0.104 & 0.003 & 0.030 & 0.901 & 0.000 & 0.425 \\
\hline $\mathrm{NRA}_{R}$ & 0.000 & 0.000 & 0.021 & 0.396 & 0.027 & 0.603 \\
\hline$\left[\mathrm{NO}_{3}{ }^{-}\right]_{\mathrm{S}}$ & 0.000 & 0.002 & 0.676 & 0.179 & 0.000 & 0.781 \\
\hline Sap pH & 0.004 & 0.870 & 0.953 & 0.201 & 0.714 & 0.439 \\
\hline
\end{tabular}

$\mathrm{TR}$, whole plant transpiration rate; WP, leaf water potential; [NO3-] $\mathrm{L}^{-}$and [NO3-]R, $\mathrm{NO}^{-}$- content in the biomass of leaves and roots; [NO3-]S, concentration of NO3- $^{-}$in xylem sap; NRAL and NRAR, NO3- reductase activity in leaves and roots; and sap $\mathrm{pH}, \mathrm{pH}$ of the xylem sap.

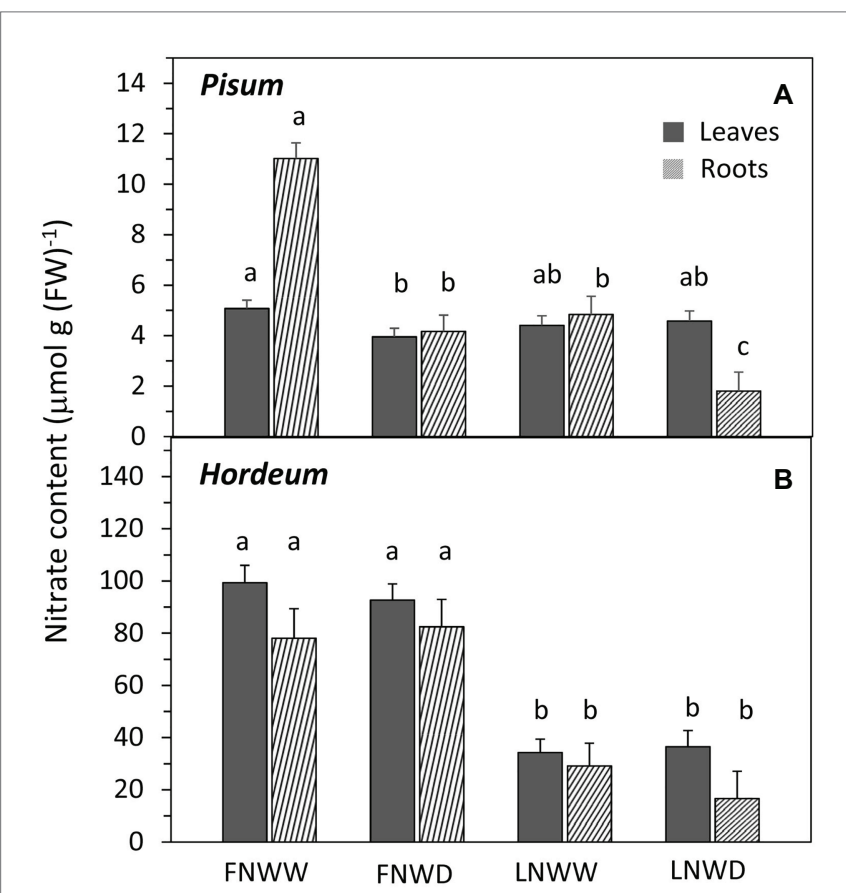

FIGURE 2 | Mean $\mathrm{NO}^{-}$content in leaf and root biomass of $P$. sativum (A) and $H$. vulgare $(\mathbf{B})$ plants after 2-6 days treatment with different water and nitrogen availability. FNWW plants received $4 \mathrm{mM} \mathrm{NO3}^{-}$daily, FNWD plants received $4 \mathrm{mM} \mathrm{NO}^{-}$at the start but no water during the sampling period, LNWW plants received $0.2 \mathrm{mM} \mathrm{NO3}^{-}$daily, and LNWD plants received 0.2 $\mathrm{mM} \mathrm{NO}^{-}$at the start but no water during the sampling period. The graph shows means \pm SE $(n=6-17)$. Significant differences $(p \leq 0.05)$ between treatments were tested separately for each organ of respective species separately and are marked by different letters. FN, full nitrogen; LN, low nitrogen; WW, well-watered; and WD, water deficient. 

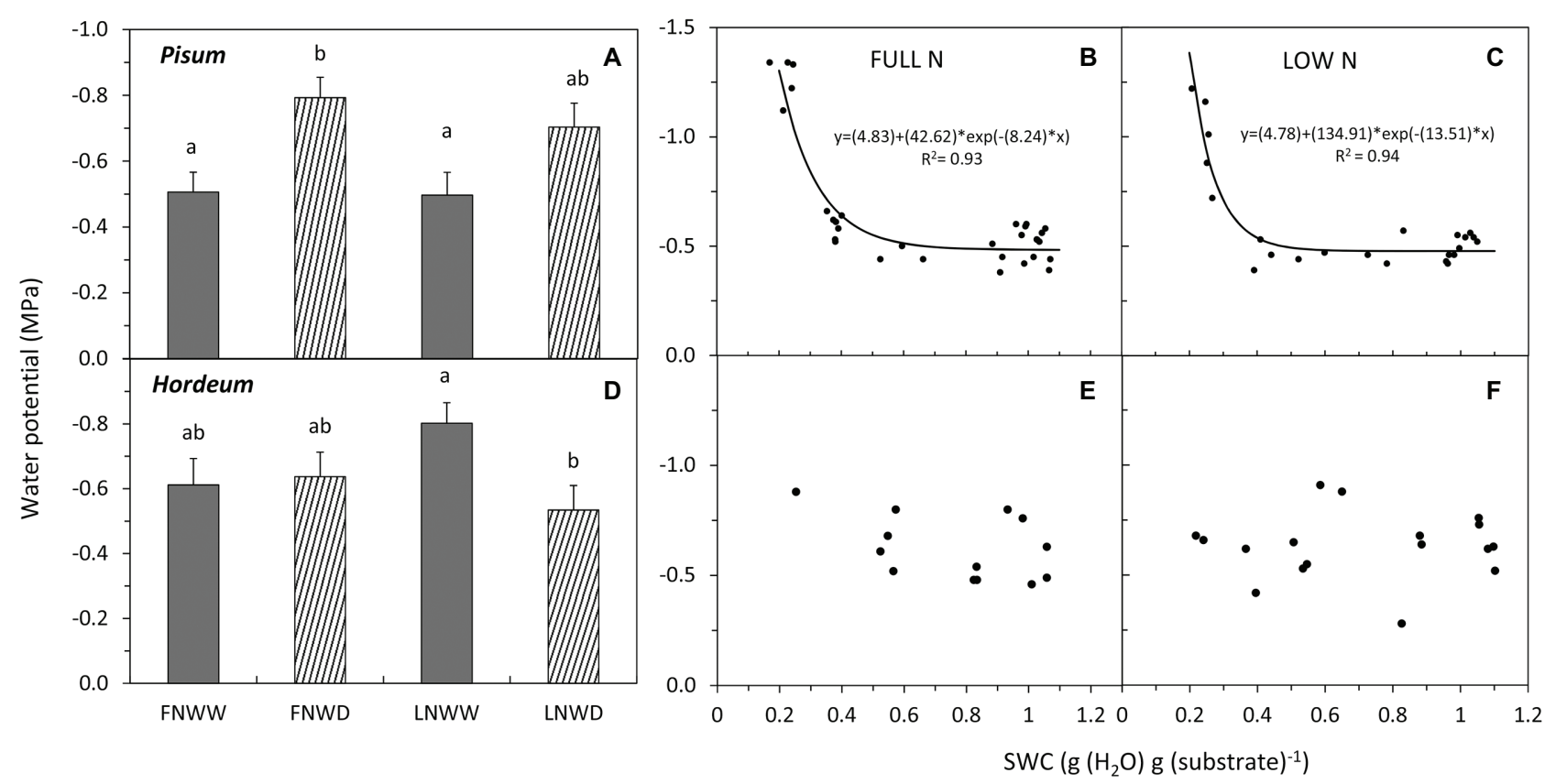

FIGURE 3 | Mean water potential (WP) of $P$. sativum $\mathbf{( A , B , C )}$ shoots and $H$. vulgare (D,E,F) leaves after 2-6 days treatment with different water and nitrogen availability. FNWW plants received $4 \mathrm{mM} \mathrm{NO3}^{-}$daily, FNWD plants received $4 \mathrm{mM} \mathrm{NO3}^{-}$at the start but no water during the sampling period, LNWW plants received $0.2 \mathrm{mM} \mathrm{NO}^{-}$daily, and LNWD plants received $0.2 \mathrm{mM} \mathrm{NO}^{-}$at the start but no water during the sampling period. The graph $(\mathbf{A}, \mathbf{D})$ shows means in each treatment \pm SE $(n=6-17)$. Significant differences $(p \leq 0.05)$ between treatments were tested separately for each species and are marked by different letters. Dynamic changes of WP with declining substrate water content (SWC) are shown in (B,C) for P. sativum; (E,F) for H. vulgare under full NO3- (FN) and low NO3 ${ }^{-}(\mathrm{LN})$ availability. Significant relationships are marked by a regression line with the corresponding equation. FN, full nitrogen; LN, low nitrogen; WW, well-watered; and WD, water deficient.

treated plants, where the decrease under low SWC was steeper (Figure 3C). Drought had a significant negative effect on $\mathrm{NO}_{3}^{-}$ content in roots of $P$. sativum but no interaction of these factors was detected (Figure 2A, Table 3). NRA was significantly reduced in roots and leaves of both species in LN treatment (Figure 4). The negative effect of drought on NRA was observed only in $P$. sativum roots, and the negative effects of $\mathrm{LN}$ and reduced water availability were synergistic (Table 3 ), resulting in a much greater decrease of NRA of roots when both stress factors were applied simultaneously (Figure 4). Reduced $\mathrm{NO}_{3}{ }^{-}$availability significantly reduced $\mathrm{NO}_{3}^{-}$transport in shoot xylem of both species (Figures 5A,D). From the group comparison, it is clear that the effect of drought was significant only under FN treatment in $P$. sativum (Figure $\mathbf{5 A}$ ).

The relationship between changes in sap $\mathrm{NO}_{3}^{-}$concentration and SWC revealed two interesting findings. Firstly, under FN treatment, substrate drying led to a gradual decrease in $\mathrm{NO}_{3}{ }^{-}$ concentration in the sap, but this effect was not apparent in LN treated plants (Figures 5C,F). Secondly, in P. sativum, we observed a transient increase in $\mathrm{NO}_{3}^{-}$concentration in moderately dry substrate (approx. $0.7-0.8 \mathrm{~g} \mathrm{~g}^{-1}=60-70 \%$ of the field water capacity, Figure 5B). The initial increase of sap $\mathrm{NO}_{3}^{-}$was confirmed also by a separate linear regression analysis of sap $\mathrm{NO}_{3}{ }^{-}$concentrations when SWC was above $0.7 \mathrm{~g} \mathrm{~g}^{-1}(p \geq 0.003)$. Xylem sap $\mathrm{pH}$ decreased in response to reduced water availability in $P$. sativum (Figure 6A; Table 3 ) but no significant response was detected in $H$. vulgare (Figure 6D; Table 3).
Moreover, the relationship between $\mathrm{pH}$ and SWC showed a transient increase in $P$. sativum xylem sap $\mathrm{pH}$, with this effect being apparent in both FN and LN treatments (Figures 6B,C). The range of SWC over which the $\mathrm{pH}$ increased was similar to that observed for the increase in sap $\mathrm{NO}_{3}{ }^{-}$concentration. No such a response was observed in $H$. vulgare plants (Figures 6E,F).

\section{DISCUSSION}

\section{Water Availability and Nitrate Utilization by Plant \\ Drought Has a Negative Effect on $\mathrm{NO}_{3}^{-}$ Availability and $\mathrm{NO}_{3}^{-}$Content}

Under drought, the $\mathrm{NO}_{3}{ }^{-}$content in biomass decreased in the majority of species we examined, implying a significant decline in $\mathrm{NO}_{3}{ }^{-}$uptake (Table 2). This effect is probably due to a reduction of mass flow or diffusion-driven uptake of $\mathrm{NO}_{3}{ }^{-}$from soil to root. It is known that short drought periods do not cause a decline in $\mathrm{N}$-uptake due to low carbon (energy) supply from the shoot (Buljovcic and Engels, 2001). Decrease of SWC hinders the movement of soil solutions, due to increased hydraulic resistance as well as the reduced root surface area in contact with soil solution (Ehlers and Goss, 2016). Root shrinkage might also reduce the contact area (Nobel and Cui, 1992). The combined effect is decreased 


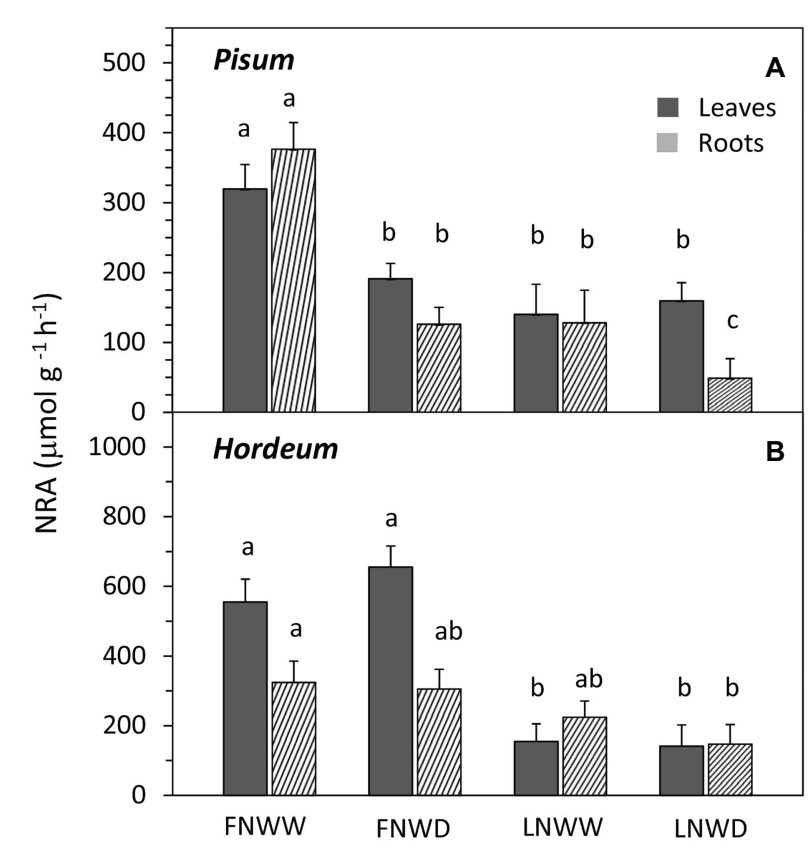

FIGURE 4 | Mean nitrate reductase activity (NRA) in leaf and root biomass of P. sativum (A) and $H$. vulgare (B) plants after 2-6 days treatment with different water and nitrogen availability. FNWW plants received 4 mM NO3- daily, FNWD plants received $4 \mathrm{mM} \mathrm{NO}^{-}$at the start but no water during the sampling period, LNWW plants received $0.2 \mathrm{mM} \mathrm{NO3}^{-}$daily, and LNWD plants received $0.2 \mathrm{mM} \mathrm{NO}^{-}$at the start but no water during the sampling period. Presented are means \pm SE $(n=6-17)$. Significant differences $(p \leq 0.05)$ between treatments were tested separately for each species and are marked by different letters. FN, full nitrogen; LN, low nitrogen; WW, wellwatered; and WD, water deficient.

delivery of $\mathrm{NO}_{3}{ }^{-}$to the root rhizodermis and its lowered uptake, unless the plant responds synthesizing new transport proteins, as suggested by Buljovcic and Engels (2001) and others (Bassett et al., 2014; Duan et al., 2016). Our results reveal a drought-induced reduction in $\mathrm{NO}_{3}{ }^{-}$-uptake, as indicated by changes in the $\mathrm{NO}_{3}{ }^{-}$content in the biomass, for $V$. faba, $N$. tabacum, and $P$. sativum but not for $H$. vulgare. Barley had the highest $\mathrm{NO}_{3}{ }^{-}$concentrations by far, and this did not change in response to drought. Moreover, it did not change much when only $0.2 \mathrm{mM} \mathrm{NO}_{3}{ }^{-}$was supplied (Figure 2B). We do not know exactly why barley is unlike other species in this respect, but it is likely due to the result of selection by breeders who have attempted to increase nitrogen uptake efficiency for barley. These selection efforts have led to changes that combine favorable root morphology with more efficient $\mathrm{NO}_{3}{ }^{-}$transporters (Bingham et al., 2012). Species with extensive root systems (e.g., Poaceae) typically show better $\mathrm{NO}_{3}{ }^{-}$ acquisition (Lainé et al., 1993).

We observed a transient but significant increase of $\mathrm{NO}_{3}^{-}$ concentration in $P$. sativum xylem sap in the early phase of drying when fully supplied (FN) with $\mathrm{NO}_{3}^{-}$(Figure 5). No such increase was detected in plants supplied with LN. This suggests that this transient increase is linked to greater $\mathrm{NO}_{3}{ }^{-}$ uptake from substrate and cannot be explained only by
$\mathrm{NO}_{3}{ }^{-}$mobilization from root cell reserves. Moreover, evaporation of water from soil might potentiate short term $\mathrm{NO}_{3}{ }^{-}$uptake by roots in as the soil concentration of $\mathrm{NO}_{3}{ }^{-}$increases when water evaporates. Nevertheless, the contribution of this effect has never been properly evaluated. This mechanism could explain the previously observed transient increase in xylem $\mathrm{NO}_{3}{ }^{-}$concentration following increased osmotic pressure of the solution (Larsson et al., 1989) or during the course of gradual drying (Wilkinson et al., 2007).

\section{Drought Affects the Distribution of Nitrate in the Plant}

Typically, higher $\mathrm{NO}_{3}{ }^{-}$concentrations were observed in roots than in leaves of the species we examined (Table 2). Lower SWC led to a relatively greater reduction in $\mathrm{NO}_{3}^{-}$in roots than in leaves. The leaf $\mathrm{NO}_{3}{ }^{-}$pool was significantly reduced in WD plants of all species except $H$. vulgare. Again, this might be attributable to better nitrogen uptake efficiency relative to other species. Field bean and pea are legumes that can fix atmospheric nitrogen (in our experiment, we used a rooting substrate that does not harbor the suitable $\mathrm{N}_{2}$ fixing symbiotic bacteria and no nodulation was observed). It is salient to note that legumes are not bred for higher abundances of root $\mathrm{NO}_{3}{ }^{-}$transporters. Tobacco is a plant that is not primarily bred for the amount but rather the quality of its biomass. In tobacco, high contents of $\mathrm{NO}_{3}{ }^{-}$or nitrile are undesirable because they are precursors of carcinogenic nitrosamines (Tso, 1972). In other words, breeding programs for nitrogen uptake efficiency are more common for barley and less relevant for the other crops. In their analysis of improvements in the nitrogen use efficiency of barley, Bingham et al. (2012) showed that over 75 years of breeding the nitrogen content of barley has increased as a result of both increased $\mathrm{N}$ uptake and utilization efficiencies. Barley might possess a more optimal composition of transporters for $\mathrm{NO}_{3}{ }^{-}$uptake enabling enough nitrogen to be taken up when the available concentration of $\mathrm{NO}_{3}^{-}$is relatively low $(0.2 \mathrm{mM})$, even in combination with reduced water availability. This is not only reflected as high $\mathrm{NO}_{3}^{-}$ concentration in $H$. vulgare shoots but also as high sap concentrations in WD plants (Table 2). The first conclusion drawn by the results is that $H$. vulgare, in comparison to $P$. sativum, seems to maintain its capacity to take up $\mathrm{NO}_{3}^{-}$ although $\mathrm{NO}_{3}{ }^{-}$and water availability are low. It should be noted that under the water limited conditions applied in our experiments, $H$. vulgare did not show signs of severe drought stress such as a significantly lower WP (Figure 3). Also, it is well known that there are large differences in response to nitrogen availability and other environmental factors affecting productivity among plant cultivars (Giles et al., 2017). Therefore, the conclusions presented here may not be readily applicable to all varieties of examined species and this fact should be considered in future experiments.

\section{Drought Negatively Affects Nitrate Assimilation}

Many studies have demonstrated the strong negative effect of water deficit on NRA in leaves (Shaner and Boyer, 1976; 

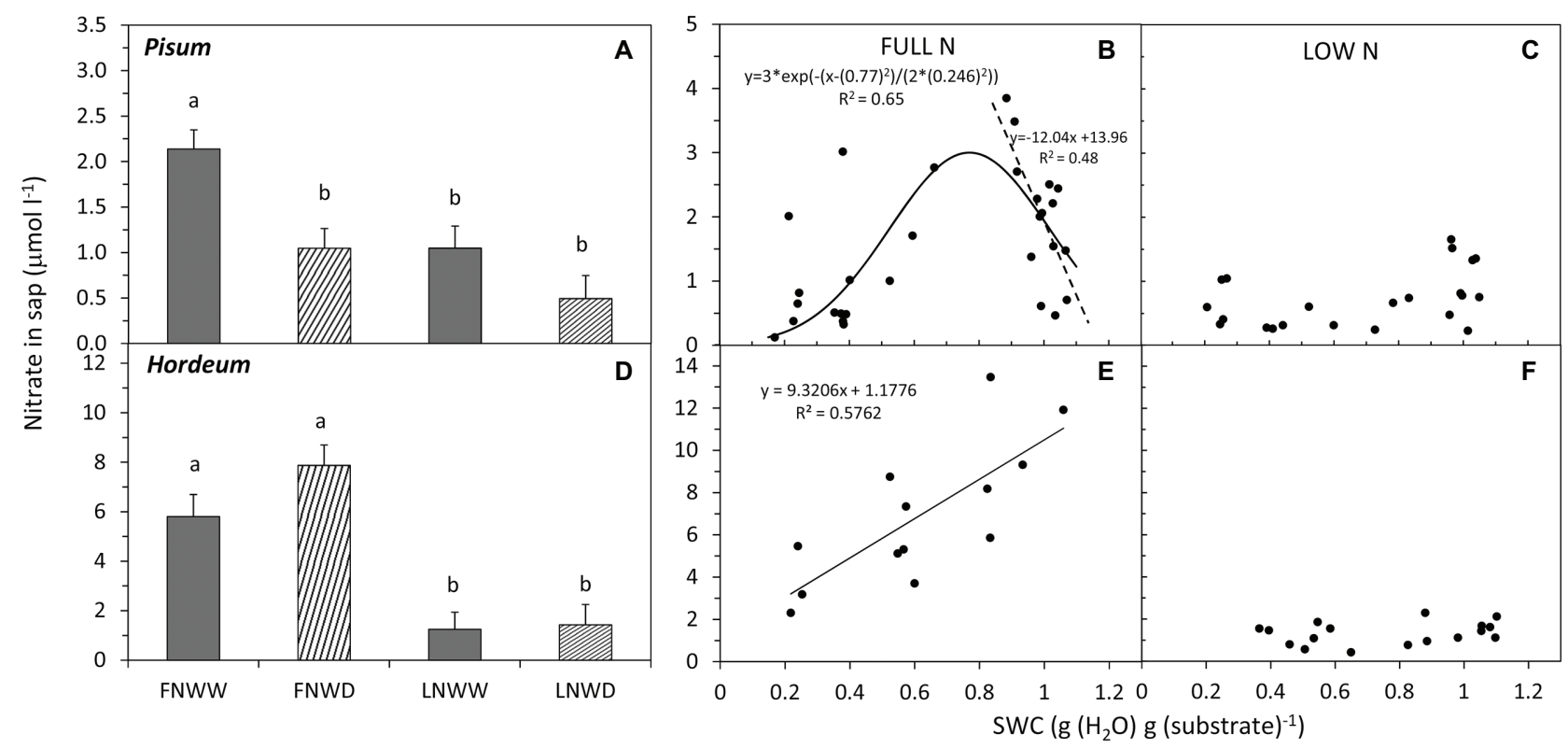

FIGURE 5 | Mean NO3- concentration in xylem sap of $P$. sativum (A,B,C) and H. vulgare (D,E,F) plants after 2-6 days treatment with different water and nitrogen availability. FNWW plants received $4 \mathrm{mM} \mathrm{NO3}{ }^{-}$daily, FNWD plants received $4 \mathrm{mM} \mathrm{NO3}{ }^{-}$at the start but no water during the sampling period, LNWW plants received $0.2 \mathrm{mM} \mathrm{NO}^{-}$daily, and LNWD plants received $0.2 \mathrm{mM} \mathrm{NO}^{-}$at the start but no water during the sampling period. The graphs (A,D) show means in each treatment \pm SE $(n=6-17)$. Significant differences $(p \leq 0.05)$ between treatments were tested separately for each species and are marked by different letters. Dynamic changes of $\mathrm{NO}^{-}$concentration in sap with declining substrate water content (SWC) are shown in (B,C) for $P$. sativum; (E,F) for $H$. vulgare under full (FN) and low (LN) NO3- availability. Significant relationships are marked by a regression line with the corresponding equation. In graph (B), the separate linear regression line was fitted only to SWC above $0.7 \mathrm{~g} . \mathrm{g}^{-1}$ (significant at $p \leq 0.003$ ). FN, full nitrogen; LN, low nitrogen; WW, well-watered; and WD, water deficient.

Larsson et al., 1989; Foyer et al., 1998) and roots (Azedo-Silva et al., 2004). That water deficit has a more significant impact on $\mathrm{NO}_{3}{ }^{-}$assimilation than on $\mathrm{NO}_{3}^{-}$uptake was suggested by Lawlor and Cornic (2002) as they observed a sharp decline in NRA under drought conditions, which was correlated with a reduction of relative water content. In our experiments, NRA was always reduced in roots and leaves of WD treated plants - with the salient exception of barley (Table 2). The major difference between barley and the other three species was that $\mathrm{NO}_{3}{ }^{-}$content was not reduced by a water deficit. This clearly indicates that availability of the NR substrate $\left(\mathrm{NO}_{3}{ }^{-}\right)$is more relevant for $\mathrm{NR}$ activity as opposed to other drought-related regulatory signals. Shaner and Boyer (1976) showed that decline in transport of $\mathrm{NO}_{3}{ }^{-}$ to shoot can be more closely related to NRA than total content of $\mathrm{NO}_{3}^{-}$in leaf biomass of maize. In WD treatment of our experiments was $\mathrm{NO}_{3}{ }^{-}$delivery to leaves also reduced. Possible "buffering effect" of high $\mathrm{NO}_{3}^{-}$in biomass and relatively smaller decrease in delivery rate in comparison to other examined species can be possible explanation of this different result. Besides $\mathrm{NO}_{3}{ }^{-}$availability (Kaiser et al., 2002), the availability of carbohydrates (Larios et al., 2001), or products of nitrogen assimilation (Scheible et al., 1997) may have also been shown to have a regulatory effect on NRA. More detailed analysis of the relationship between $\mathrm{NO}_{3}^{-}$transport and NRA, including other regulatory signals, represents the next logical step in clarifying uncertainties related to the early impact of drought on nitrogen assimilation in barley.

\section{Nitrate Availability and Plant Response to Drought Early Response to Drought and Nitrate Assimilation}

In our experiments, we tested the hypothesis that $\mathrm{NO}_{3}^{-}$ availability is not only affected by reduced water availability in the substrate but it can also modulate the plant drought response. Lips (1997) proposed a model explaining how $\mathrm{NO}_{3}{ }^{-}$can be involved in the plant drought response. Declining water availability would reduce $\mathrm{NO}_{3}{ }^{-}$uptake and transport to the shoot. This change then triggers a relatively larger decrease of NRA in the shoot rather than the root. Consequently, the increased proportion of NRA in roots would increase xylem sap $\mathrm{pH}$ due to the export of organic acids anions from the symplast into the apoplast (organic acid anions are formed during $\mathrm{NO}_{3}{ }^{-}$reduction; see Introduction for details). Our experiments with four species indeed show that $\mathrm{NO}_{3}{ }^{-}$concentration in organs and $\mathrm{NO}_{3}{ }^{-}$ transport to the shoot are mostly reduced even in the early phase of drought (Tables 2, 3), presumably due to restricted $\mathrm{NO}_{3}{ }^{-}$uptake. On the other hand, under drought conditions, NRA was always more reduced in roots than in leaves. This was the case in all species that differed in the primary contribution of leaves and roots to plant $\mathrm{NO}_{3}{ }^{-}$assimilation - 

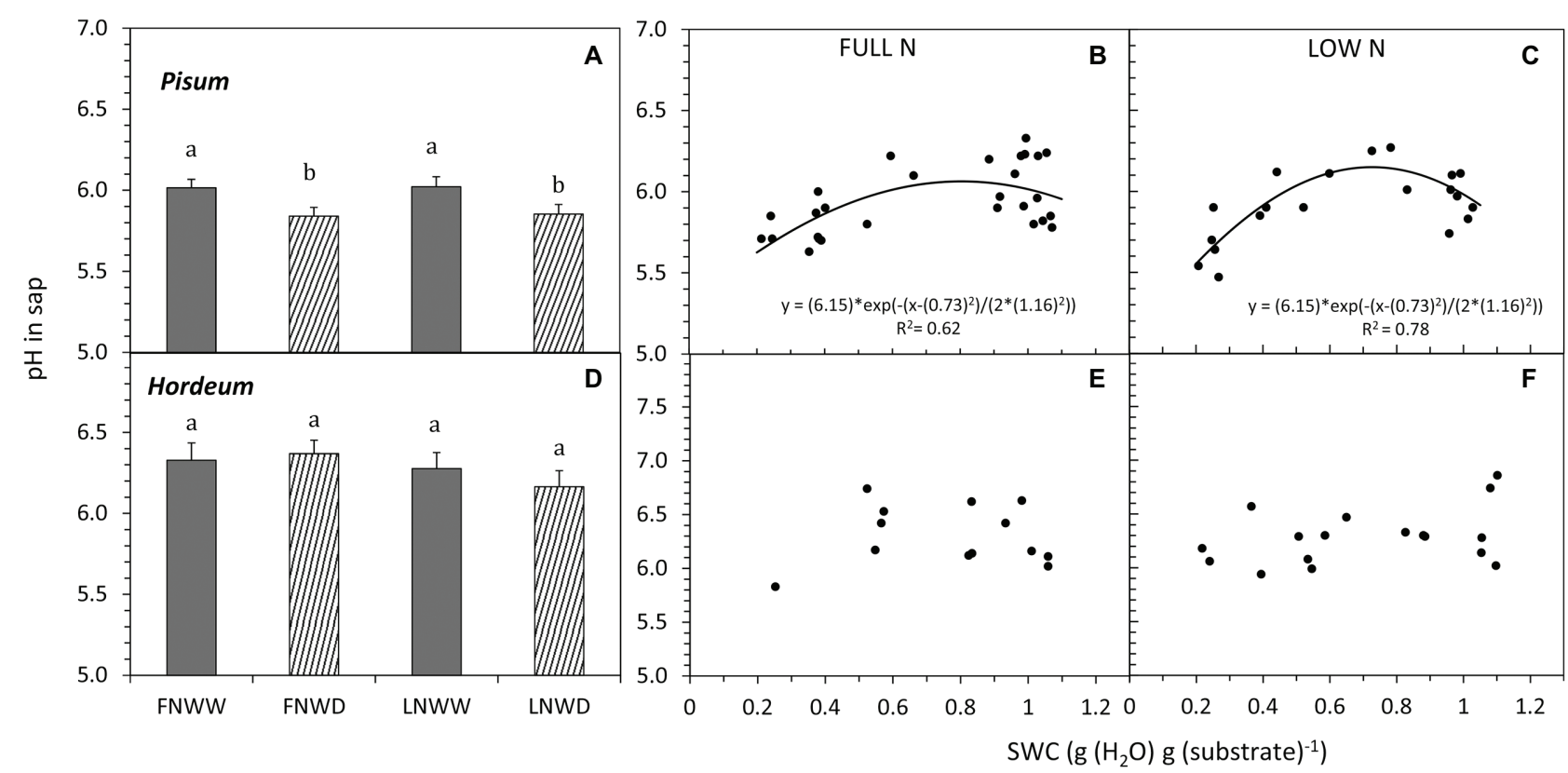

FIGURE 6 | Mean pH in xylem sap (pH in sap) of $P$. sativum (A,B,C) and $H$. vulgare (D,E,F) plants after 2-6 days of treatments with different water and nitrogen availability. FNWW plants received $4 \mathrm{mM} \mathrm{NO3}^{-}$daily, FNWD plants received $4 \mathrm{mM} \mathrm{NO}^{-}$at the start but no water during the sampling period, LNWW plants received $0.2 \mathrm{mM} \mathrm{NO}^{-}$- daily, and LNWD plants received $0.2 \mathrm{mM} \mathrm{NO}^{-}$at the start but no water during the sampling period. The graphs (A,D) show means in each treatment \pm SE $(n=6-17)$. Significant differences $(p \leq 0.05)$ between treatments were tested separately for each species and are marked by different letters. Dynamic changes of $\mathrm{pH}$ in sap with declining SWC are shown in (B,C) for P. sativum; (E,F) for H. vulgare under full (FN) and low (LN) NO3- availability. Significant relationships are marked by a regression line with the corresponding equation. FN, full nitrogen; LN, low nitrogen; WW, well-watered; and WD, water deficient.

legumes with relatively higher NRA in roots vs. non-legumes with rather equal distribution of NRA (Table 2). Therefore, the increased sap $\mathrm{pH}$ due to a shift of NRA from leaves to roots seems unlikely, just like the sequence of events that lead to $\mathrm{pH}$-driven ABA accumulation as described above. In fact, we did not observe sap alkalization in any of the examined species when we compared only WW and WD treatments. On the contrary, V. faba and P. sativum responded to drought by sap acidification. Correlation analysis of data also did not find any relationship between NRA either in leaves or in roots and sap $\mathrm{pH}$ in $P$. sativum, $H$. vulgare, and N. tabacum. This result fits well with our previous multi-species study, which showed that the dominant site of $\mathrm{NO}_{3}{ }^{-}$reduction has no effect on sap $\mathrm{pH}$ under drought (Gloser et al., 2016). On the other hand, reduced $\mathrm{NO}_{3}{ }^{-}$ uptake and transport under declining SWC can lead to changes in sap $\mathrm{pH}$. Changes of sap $\mathrm{pH}$ of both $P$. sativum and $H$. vulgare were, however, similar in both FN and LN treatments (Figure 6), suggesting that a short-term reduction in $\mathrm{NO}_{3}{ }^{-}$availability has little or no effect on sap $\mathrm{pH}$. Thus, we can clearly say that our data collected from four different species do not support the model proposed by Lips (1997).

\section{Consequences of Short-Term Low Nitrogen Treatment Under Drought}

We used two species, namely P. sativum and H. vulgare, for follow-up experiments where the combined effects of short-term deficiency of both water and nitrogen were analyzed in detail. For both species, there were no short-term effects of $\mathrm{NO}_{3}{ }^{-}$ availability on the whole plant TR (Figure 1). This is not surprising considering that leaf $\mathrm{NO}_{3}{ }^{-}$concentration was stable over the experimental time frame in $P$. sativum plants that were supplied with $0.2 \mathrm{mM} \mathrm{NO}_{3}^{-}$relative to plants supplied with $4 \mathrm{mM} \mathrm{NO}_{3}^{-}$(Figure 2). In $\mathrm{H}$. vulgare, there was a significant decrease in $\mathrm{NO}_{3}^{-}$, and yet leaf $\mathrm{NO}_{3}{ }^{-}$concentration was eight times higher compared to $P$. sativum leaves (Figure 1). In other words, we assume that the reduction in leaf $\mathrm{NO}_{3}{ }^{-}$ amount in the LN treatment of plants in solid media was not strong and fast enough over the duration of the experiment. It could explain different conclusions of Chapin et al. (1988) where $\mathrm{NO}_{3}{ }^{-}$content in the leaves of plants rapidly transferred to $\mathrm{N}$-free solution decreased to $30-40 \%$ of control plants within 2 days. They also observed a simultaneous decrease in TR, probably as a consequence of higher ABA concentration in leaves.

In our short-term experiments, we also did not observe any interactive effects of $\mathrm{NO}_{3}{ }^{-}$and water deficiency on TR. We found a transient increase of sap $\mathrm{pH}$ in P. sativum. This pattern of $\mathrm{pH}$ change has been previously observed in some other species (Gloser et al., 2016) but the origin and the regulatory implications for the leaf apoplast remain unclear. We therefore conclude that $\mathrm{NO}_{3}{ }^{-}$availability in soil is not linked to the modulation of transpiration in the short-term (up to 2-6 days) as long as leaf $\mathrm{NO}_{3}{ }^{-}$levels remain stable. Lower $\mathrm{NO}_{3}^{-}$levels in leaves, however, may 
contribute to stomatal regulation over longer periods of $\mathrm{N}$-starvation as suggested by Chapin et al. (1988).

\section{DATA AVAILABILITY STATEMENT}

The raw data supporting the conclusions of this article will be made available by the authors, to any qualified researcher after request.

\section{AUTHOR CONTRIBUTIONS}

VG and CG conceptualized the main research questions, designed experiments and wrote the manuscript. VG, MD, DM, BP, and PG collected data. VG and MD performed the data analyses. All authors contributed to the article and approved the submitted version.

\section{REFERENCES}

Andrews, M. (1986). The partitioning of nitrate assimilation between root and shoot of higher plants. Plant Cell Environ. 9, 511-519. doi: 10.1111/1365-3040. ep11616228

Araus, V., Swift, J., Alvarez, J. M., Henry, A., and Coruzzi, G. M. (2020). A balancing act: how plants integrate nitrogen and water signals. J. Exp. Bot. 71, 4442-4451. doi: 10.1093/jxb/eraa054

Azedo-Silva, J., Osório, J., Fonseca, F., and Correia, M. J. (2004). Effects of soil drying and subsequent re-watering on the activity of nitrate reductase in roots and leaves of Helianthus annuus. Funct. Plant Biol. 31, 611-621. doi: 10.1071/FP04018

Bassett, C. L., Baldo, A. M., Moore, J. T., Jenkins, R. M., Soffe, D. S., Wisniewski, M. E., et al. (2014). Genes responding to water deficit in apple (Malus $\times$ domestica Borkh.) roots. BMC Plant Biol. 14:182. doi: 10.1186/14712229-14-182

Bingham, I. J., Karley, A. J., White, P. J., Thomas, W. T. B., and Russell, J. R. (2012). Analysis of improvements in nitrogen use efficiency associated with 75 years of spring barley breeding. Eur. J. Agron. 42, 49-58. doi: 10.1016/j. eja.2011.10.003

Black, B. L., Fuchigami, L. H., and Coleman, G. D. (2002). Partitioning of nitrate assimilation among leaves, stems and roots of poplar. Tree Physiol. 22, 717-724. doi: 10.1093/treephys/22.10.717

Boyer, J. S. (1967). Leaf water potentials measured with a pressure chamber. Plant Physiol. 42, 133-137. doi: 10.1104/pp.42.1.133

Brewitz, E., Larsson, C. -M., and Larsson, M. (1996). Responses of nitrate assimilation and $\mathrm{N}$ translocation in tomato (Lycopersicon esculentum mill) to reduced ambient air humidity. J. Exp. Bot. 47, 855-861. doi: 10.1093/ $\mathrm{jxb} / 47.7 .855$

Buljovcic, Z., and Engels, C. (2001). Nitrate uptake ability by maize roots during and after drought stress. Plant Soil 229, 125-135. doi: 10.1023/A:10 04879201623

Cataldo, D. A., Haroon, M., Schrader, L. E., and Youngs, V. L. (1975). Rapid colorimetric determination of nitrate in plant tissue by nitration of salicylic acid. Commun. Soil Sci. Plant Anal. 61, 71-80. doi: 10.1080/00103627509366547

Chapin, F. S. III. (1991). Integrated responses of plants to stress. Bioscience 41, 29-36. doi: 10.2307/1311538

Chapin, F. S. III., Walter, C. H., and Clarkson, D. T. (1988). Growth response of barley and tomato to nitrogen stress and its control by abscisic acid, water relations and photosynthesis. Planta 173, 352-366. doi: 10.1007/ BF00401022

Correia, M. J., Fonseca, F., Azedo-Silva, J., Dias, C., David, M. M., Barrote, I., et al. (2005). Effects of water deficit on the activity of nitrate reductase and content of sugars, nitrate and free amino acids in the leaves and roots of

\section{FUNDING}

This work supported by the German Academic Exchange Service and The Czech Ministry of Education Youth and Sports via the bilateral project MOBILITY grant (reg. no. 8J19DE007) and by a BMBF research grant (CUBES Circle 031B0733A), which is gratefully acknowledged.

\section{ACKNOWLEDGMENTS}

We thank Oldřich Jůza for valuable technical assistance.

\section{SUPPLEMENTARY MATERIAL}

The Supplementary Material for this article can be found online at: https://www.frontiersin.org/articles/10.3389/fpls.2020.602065/ full\#supplementary-material

sunflower and white lupin plants growing under two nutrient supply regimes. Physiol. Plant. 124, 61-70. doi: 10.1111/j.1399-3054.2005.00486.x

Davies, W. J., Wilkinson, S., and Loveys, B. (2002). Stomatal control by chemical signalling and the exploitation of this mechanism to increase water use efficiency in agriculture. New Phytol. 153, 449-460. doi: 10.1046/j.0028646X.2001.00345.x

Dijkshoorn, W. (1962). Metabolic regulation of the alkaline effect of nitrate utilization in plants. Nature 194, 165-167. doi: 10.1038/194165a0

Dodd, I. C., Theobald, J. C., Richer, S. K., and Davies, W. J. (2009). Partial phenotypic reversion of ABA-deficient flacca tomato (Solanum lycopersicum) scions by a wild-type rootstock: normalizing shoot ethylene relations promotes leaf area but does not diminish whole plant transpiration rate. J. Exp. Bot. 60, 4029-4039. doi: 10.1093/jxb/erp236

Duan, J., Tian, H., and Gao, Y. (2016). Expression of nitrogen transporter genes in roots of winter wheat (Triticum aestivum L.) in response to soil drought with contrasting nitrogen supplies. Crop Past Sci. 67, 128-136. doi: $10.1071 / \mathrm{CP} 15152$

Ehlers, W., and Goss, M. (2016). Water dynamics in plant production. 2nd Edn. Wallingford, Boston: CABI.

Foyer, C. H., Valadier, M. H., Migge, A., and Becker, T. H. (1998). Droughtinduced effects on nitrate reductase activity and mRNA and on the coordination of nitrogen and carbon metabolism in maize leaves. Plant Physiol. 117, 283-292. doi: 10.1104/pp.117.1.283

Geilfus, C. M., Mithöfer, A., Ludwig-Müller, J., Zörb, C., and Muehling, K. H. (2015). Chloride-inducible transient apoplastic alkalinizations induce stomata closure by controlling abscisic acid distribution between leaf apoplast and guard cells in salt-stressed Vicia faba. New Phytol. 208, 803-816. doi: 10.1111/nph.13507

Geilfus, C. M., Tenhaken, R., and Carpentier, S. C. (2017). Transient alkalinization of the leaf apoplast stiffens the cell wall during onset of chloride salinity in corn leaves. J. Biol. Chem. 292, 18800-18813. doi: 10.1074/jbc.M117.799866

Giles, C. D., Brown, L. K., Adu, M. O., Mezeli, M. M., Sandral, G. A., Simpson, R. J., et al. (2017). Response-based selection of barley cultivars and legume species for complementarity: root morphology and exudation in relation to nutrient source. Plant Sci. 255, 12-28. doi: 10.1016/j.plantsci. 2016.11.002

Gloser, V., Korovetska, H., Martin-Vertedor, A. I., Hájíčková, M., Prokop, Z., Wilkinson, S., et al. (2016). The dynamics of xylem sap pH under drought: a universal response in herbs? Plant Soil 409, 259-272. doi: 10.1007/ s11104-016-2962-6

Gollan, T., Schurr, U., and Schulze, E. D. (1992). Stomatal response to drying soil in relation to changes in the xylem sap composition of Helianthus annuus. I. the concentration of cations, anions, amino acids in, and $\mathrm{pH}$ of, the xylem sap. Plant Cell Environ. 155, 551-559. doi: 10.1111/j.1365-3040. 1992.tb01488.x 
Goodger, J. Q. D., Sharp, R. E., Marsh, E. L., and Schachtman, D. P. (2005). Relationships between xylem sap constituents and leaf conductance of wellwatered and water-stressed maize across three xylem sap sampling techniques. J. Exp. Bot. 56, 2389-2400. doi: 10.1093/jxb/eri231

Hachiya, T., and Sakakibara, H. (2017). Interactions between nitrate and ammonium in their uptake, allocation, assimilation, and signaling in plants. J. Exp. Bot. 68, 2501-2512. doi: 10.1093/jxb/erw449

Jia, W., and Davies, W. J. (2007). Modification of leaf apoplastic pH in relation to stomatal sensitivity to root-sourced abscisic acid signals. Plant Physiol. 143, 68-77. doi: 10.1104/pp.106.089110

Kaiser, W. M., Weiner, H., Kandlbinder, A., Tsai, C. -B., Rockel, P., Sonoda, M., et al. (2002). Modulation of nitrate reductase: some new insights, an unusual case and a potentially important side reaction. J. Exp. Bot. 53, 875-882. doi: $10.1093 /$ jexbot/53.370.875

Karuppanapandian, T., Geilfus, C. M., Muehling, K. H., Novák, O., and Gloser, V. (2017). Early changes of the $\mathrm{pH}$ of the apoplast are different in leaves, stem and roots of Vicia faba L. under declining water availability. Plant Sci. 255, 51-58. doi: 10.1016/j.plantsci.2016.11.010

Lainé, P., Ourry, A., Macduff, J., Boucaud, J., and Salette, J. (1993). Kinetic parameters of nitrate uptake by different catch crop species: effects of low temperatures or previous nitrate starvation. Physiol. Plant. 88, 85-92. doi: 10.1111/j.1399-3054.1993.tb01764.x

Larios, B., Aguera, E., de la Haba, P., Perez-Vicente, R., and Maldonado, J. M. (2001). A short-term exposure of cucumber plants to rising atmospheric $\mathrm{CO}_{2}$ increases leaf carbohydrate content and enhances nitrate reductase expression and activity. Planta 212, 305-312. doi: 10.1007/s004250000395

Larsson, M., Larsson, C. M., Whitford, P. N., and Clarkson, D. T. (1989). Influence of osmotic stress on nitrate reductase activity in wheat (Triticum aestivum L.) and the role of abscisic acid. J. Exp. Bot. 40, 1265-1271. doi: 10.1093/jxb/40.11.1265

Lawlor, D. W., and Cornic, G. (2002). Photosynthetic carbon assimilation and associated metabolism in relation to water deficits in higher plants. Plant Cell Environ. 25, 275-294. doi: 10.1046/j.0016-8025.2001.00814.x

Li, W., de Ollas, C., and Dodd, I. C. (2018). Long-distance ABA transport can mediate distal tissue responses by affecting local ABA concentrations. J. Integr. Plant Biol. 60, 16-33. doi: 10.1111/jipb.12605

Lips, S. H. (1997). The role of inorganic nitrogen ions in plant adaptation processes. Russ. J. Plant Physiol. 44, 421-431.

Lu, C., and Zhang, J. (2000). Photosynthetic $\mathrm{CO}_{2}$ assimilation, chlorophyll fluorescence and photoinhibition as affected by nitrogen deficiency in maize plants. Plant Sci. 151, 135-143. doi: 10.1016/S0168-9452(99)00207-1

Marschner, H. (1995). Mineral nutrition of higher plants. Cambridge: Academic Press, 889.

Matimati, I., Verboom, G. A., and Cramer, M. D. (2014). Nitrogen regulation of transpiration controls mass-flow acquisition of nutrients. J. Exp. Bot. 65, 159-168. doi: 10.1093/jxb/ert367

McAdam, S. A., Manzi, M., Ross, J. J., Brodribb, T. J., and Gómez-Cadenas, A. (2016). Uprooting an abscisic acid paradigm: shoots are the primary source. Plant Signal. Behav. 11, 652-659. doi: 10.1080/15592324.2016.1169359

Nobel, P. S., and Cui, M. (1992). Shrinkage of attached roots of Opuntia ficus-indica in response to lowered water potentials-predicted consequences for water uptake or loss to soil. Ann. Bot. 70, 485-491. doi: 10.1093/ oxfordjournals.aob.a088508

Peuke, A. D., Glaab, J., Kaiser, W. M., and Jeschke, W. D. (1996). The uptake and flow of $\mathrm{C}, \mathrm{N}$ and ions between roots and shoots in Ricinus communis L. IV. Flow and metabolism of inorganic nitrogen and malate depending on nitrogen nutrition and salt treatment. J. Exp. Bot. 47, 377-385. doi: 10.1093/jxb/47.3.377

Plett, D. C., Ranathunge, K., Melino, V. J., Kuya, N., Uga, Y., and Kronzucker, H. J. (2020). The intersection of nitrogen nutrition and water use in plants: new paths toward improved crop productivity. J. Exp. Bot. 71, 4452-4468. doi: $10.1093 /$ jxb/eraa049

Roelfsema, M. R. G., Hanstein, S., Felle, H. H., and Hedrich, R. (2002). $\mathrm{CO}_{2}$ provides an intermediate link in the red light response of guard cells. Plant J. 32, 65-75. doi: 10.1046/j.1365-313X.2002.01403.x

Roelfsema, M. R. G., Konrad, K. R., Marten, H., Psaras, G. K., Hartung, W., and Hedrich, R. (2006). Guard cells in albino leaf patches do not respond to photosynthetically active radiation, but are sensitive to blue light, $\mathrm{CO}_{2}$ and abscisic acid. Plant Cell Environ. 29, 1595-1605. doi: 10.1111/j.1365-3040.2006.01536.x

Scheible, W. R., Gonzalez-Fontes, A., Morcuende, R., Lauerer, M., Geiger, M., Glaab, J., et al. (1997). Tobacco mutants with a decreased number of functional nia genes compensate by modifying the diurnal regulation of transcription, post-translational modification and turnover of nitrate reductase. Planta 203, 304-319. doi: 10.1007/s004250050196

Shaner, D. L., and Boyer, J. S. (1976). Nitrate reductase activity in maize (Zea mays L.) leaves. II. Regulation by nitrate flux at low leaf potential. Plant Physiol. 58, 505-509. doi: 10.1104/pp.58.4.505

Sharp, R. G., and Davies, W. J. (2009). Variability among species in the apoplastic $\mathrm{pH}$ signalling response to drying soils. J. Exp. Bot. 60, 4363-4370. doi: 10.1093/jxb/erp273

Tezara, W., Mitchell, V. J., Driscoll, S. D., and Lawlor, D. W. (1999). Water stress inhibits plant photosynthesis by decreasing coupling factor and ATP. Nature 401, 914-917.

Tominaga, M., Kinoshita, T., and Shimazaki, K. (2001). Guard-cell chloroplasts provide ATP required for $\mathrm{H} 1$ pumping in the plasma membrane and stomatal opening. Plant Cell Physiol. 42, 795-802. doi: 10.1093/pcp/pce101

Tso, T. C. (1972). Physiology and biochemistry of tobacco plants. Stroudsburg: Dowden, Hutchinson \& Ross, Inc.

Wilkinson, S. (2004). "Water use efficiency and chemical signalling" in Water use efficiency in plant biology. ed. M. A. Bacon (Oxford: Blackwell Publishing Ltd), 75-112.

Wilkinson, S., Bacon, M. A., and Davies, W. J. (2007). Nitrate signalling to stomata and growing leaves: interactions with soil drying, ABA and xylem sap pH in maize. J. Exp. Bot. 58, 1705-1716. doi: 10.1093/jxb/erm021

Wilkinson, S., Corlett, J. E., Oger, L., and Davies, W. J. (1998). Effects of xylem $\mathrm{pH}$ on transpiration from wild-type and flacca tomato leaves: a vital role for abscisic acid in preventing excessive water loss even from wellwatered plants. Plant Physiol. 117, 703-709. doi: 10.1104/pp.117.2.703

Wilkinson, S., and Davies, W. J. (1997). Xylem sap pH increase: a drought signal received at the apoplastic face of the guard cell that involves the suppression of saturable abscisic acid uptake by the epidermal symplast. Plant Physiol. 113, 559-557. doi: 10.1104/pp.113.2.559

Wilkinson, S., and Davies, W. J. (2002). ABA-based chemical signalling: the co-ordination of responses to stress in plants. Plant Cell Environ. 25, 195-210. doi: $10.1046 / \mathrm{j} .0016-8025.2001 .00824 . \mathrm{x}$

Conflict of Interest: The authors declare that the research was conducted in the absence of any commercial or financial relationships that could be construed as a potential conflict of interest.

Copyright (C) 2020 Gloser, Dvorackova, Mota, Petrovic, Gonzalez and Geilfus. This is an open-access article distributed under the terms of the Creative Commons Attribution License (CC BY). The use, distribution or reproduction in other forums is permitted, provided the original author(s) and the copyright owner(s) are credited and that the original publication in this journal is cited, in accordance with accepted academic practice. No use, distribution or reproduction is permitted which does not comply with these terms. 